\title{
Peningkatan Kontrol Sosial Masyarakat Dalam \\ Upaya Pencegahan Penyalahgunaan NAPZA
}

\author{
Oleh: Putra Pratama Saputra, MPS.Sp
}

\begin{abstract}
The drug abuse problem that occured in society these days is very alarming. The existence of the perpetrator and the activity of drug abuse has become a custom of the community. However, permissiveness shown as if the people let these problems occur. The existence of stakeholders is expected to have a positive impact, so that the functions of society can work well, especially in the prevention of drug abuse. The improvement of society social control is an effort to prevent drug abuse. The purpose of this research is to improve the society social control as away to prevent drug abuse. The method used in this research is a qualitative research method with action research. The Place of research conducted in RW 18 Sadang Serang Village, Coblong Sub-district, Bandung with a number of main informants and supporting informant were 6 people as many as 3 people. The intervention is done through several activities, namely the Counseling and Socialization, Social Campaign, and Forming Local Organization "Pemuda Anti NAPZA". The results showed an increase in society social control is an effort to prevent drug abuse in RW 18 Sadang Serang Village. Final model has been enhanced tends to be more effective in addressing the problem of drug abuse which is occured.
\end{abstract}

Key Words: Social Control, Society, NAPZA (Narcotics, Psychotropics and Addicted Subtances), and Preventing Drugs Abuse.

\section{A. Latar Belakang}

1. Pendahuluan

Mengulas tentang pemaknaan dari NAPZA, NAPZA itu sendiri memiliki arti, yaitu: Narkotika, Psikotropika, dan Zat Adiktif Lainnya. Selain itu juga, ada yang menyebutnya NARKOBA (Narkotika dan Obat-obat Berbahaya) atau NAZA (Narkotika dan Zat Adiktif). NAPZA (Narkotika, Psikotropika, dan Zat Adiktif Lainnya) adalah bahan/zat/obat yang bila masuk ke dalam tubuh manusia akan mempengaruhi tubuh terutama otak/susunan saraf pusat, sehingga menyebabkan gangguan kesehatan fisik, psikis, dan fungsi sosialnya karena terjadi kebiasaan, ketagihan (adiksi), serta ketergantungan (dependensi) terhadap NAPZA. Istilah NAPZA umumnya digunakan oleh sektor pelayanan kesehatan, yang menitikberatkan pada upaya penanggulangan dari sudut kesehatan fisik, psikis, dan sosial. NAPZA sering disebut juga sebagai zat psikoaktif, yaitu: zat yang bekerja pada otak, sehingga menimbulkan perubahan pikiran perasaan, perilaku, perasaan, dan sikap.

Masalah penyalahgunaan NAPZA sekarang ini sudah merupakan bencana nasional. Hal ini ditandai dengan dicanangkannya "Indonesia Darurat Narkoba", makin meningkatnya jumlah populasi penyalahgunaan, kompleksitas permasalahan, maupun jenis zat yang disalahgunakan. Berdasarkan data Badan Narkotika Nasional (BNN) Kota Bandung dan Satuan Reserse Narkoba Kepolisian Resort Kota Besar Bandung, pada tahun 2015 sebanyak 555 kasus penyalahgunaan NAPZA dan hampir setiap tahunnya mengalami peningkatan yang cukup signifikan. Untuk saat ini lebih dari 300 tersangka yang mendekam di Tahanan Satuan Reserse Narkoba Kepolisian Resort Kota Besar Bandung dikarenakan kasus penyalahgunaan NAPZA. Pelaku penyalahgunaan NAPZA di Kota Bandung berusia di bawah 20 tahun dan di atas 30 tahun. Namun, yang paling banyak berada pada usia di atas 30 tahun dengan jumlah 61 persen. Korban 
penyalahgunaan NAPZA memiliki pekerjaaan yang beragam, yaitu: anggota TNI/POLRI, Pegawai Negeri Sipil (PNS), pegawai swasta, wiraswasta, mahasiswa/pelajar, tunakarya, dan profesi lainnya. Dilihat dari tingkat pendidikan, korban penyalahgunaan NAPZA yang tertinggi terjadi pada lulusan SLTA dan terendah terjadi pada lulusan Sarjana. Tempat yang menjadi lokasi transaksi atau tindak pidana, yaitu: tempat keramaian, tempat permukiman, jalan umum, sekitar sekolah/kampus, dan lain-lainnya. Badan Narkotika Nasional (BNN) Kota Bandung telah menyediakan program rehabilitasi untuk 750 orang. Akan tetapi, korban penyalahgunaan NAPZA yang baru mendaftar untuk di rehabilitasi sebanyak 274 orang. Beberapa pusat rehabilitasi untuk merawat korban penyalahgunaan NAPZA yang ada di Kota Bandung, yaitu: RSUD Ujung Berung, Puskesmas Ibrahim Adjie, Puskesmas Kopo, Puskesmas Pasir Kaliki, Klinik Yabes, Rumah Cemara, Sekar Mawar, dan lain-lainnya.

Pemerintah telah mengeluarkan beberapa kebijakan dan program pencegahan dan penanganan penyalahgunaan NAPZA. Salah satu bentuknya berupa "Gerakan Nasional Rehabilitasi 100.000 Korban Penyalahgunaan Narkoba". Upaya rehabilitasi dilakukan oleh Kementerian Sosial dan Kementerian Kesehatan. Kementerian Sosial berkaitan dengan rehabilitasi sosial bagi korban penyalahgunaan NAPZA, sementara Kementerian Kesehatan berkaitan dengan rehabilitasi medis bagi korban penyalahgunaan NAPZA. Badan Narkotika Nasional (BNN) dalam hal ini berperan dalam upaya pencegahan dan keterkaitan dengan aspek hukum para pelaku penyalahguna NAPZA. Program "Gerakan Nasional Rehabilitasi 100.000 Korban Penyalahgunaan Narkoba" bertujuan untuk menurunkan jumlah pemakaian NAPZA. Hal ini dikarenakan dalam upaya pencegahan dan penanganan penyalahgunaan NAPZA tidak bisa dilakukan oleh 1 leading sector. Perlu adanya kerjasama dari berbagai pihak, baik pemerintah maupun swasta.

Masalah penyalahgunaan NAPZA di Kelurahan Sadang Serang menjadi sorotan sebagai wilayah yang rawan terhadap masalah penyalahgunaan NAPZA dikarenakan banyak terjadi kasus-kasus yang berhubungan dengan masalah penyalahgunaan NAPZA. Hasil asesmen yang dilakukan melalui metode partisipatif (focus group discussion) dan metode non partisipatif (wawancara mendalam, observasi partisipatif, dan studi dokumentasi), menunjukkan bahwa wilayah yang rentan terhadap masalah penyalahgunaan NAPZA yang ada di Kelurahan Sadang Serang, yaitu: RW 15, 16, 18, dan 19. Berdasarkan hasil wawancara mendalam, observasi partisipatif, studi dokumentasi, dan FGD menggambarkan bahwa wilayah RW 18 rentan terhadap masalah penyalahgunaan NAPZA. Beberapa pertimbangan yang menjadi alasan peneliti menentukan RW 18 Kelurahan Sadang Serang sebagai lokasi penelitian, yaitu: di RW 18 pernah terjadi penggerebekan kasus penyalahgunaan NAPZA, banyaknya lokasi yang menjadi tempat untuk mengkonsumsi minuman alkohol, sering terjadinya perkelahian dan perjudian, wilayah yang berdekatan dengan Pasar Tilil dan Terminal Sadang Serang, kurangnya pengetahuan dan pemahaman masyarakat terhadap masalah penyalahgunaan NAPZA, tidak adanya dukungan masyarakat terhadap masalah penyalahgunaan NAPZA, serta kurangnya kontrol sosial masyarakat terhadap masalah penyalahgunaan NAPZA.

Upaya tokohmasyarakatbaik secaralangsung maupun tidak langsung sangat dibutuhkan dalam usaha pencegahan penyalahgunaan NAPZA. Masalah penyalahgunaan NAPZA dapat memisahkan antara orang tua dengan anak, keluarga, dan saudaranya. Apabila tidak ditanggulangi secara tuntas, maka kita akan kehilangan generasi penerus selanjutnya. Usaha dalam pencegahan penyalahgunaan NAPZA, bukanlah semata-mata untuk kepentingan korban penyalahguna ataupun pihak lain, tetapi demi terhindarnya dan mencegah penyebaran penyalahgunaan NAPZA yang akan menimbulkan korban lain di lingkungan masyarakat itu sendiri.

Sehubungan dengan hal di atas maka peneliti tertarik untuk melakukan penelitian tentang 
"Peningkatan Kontrol Sosial Masyarakat Dalam Upaya Penceahan Penyalahgunaan NAPZA di RW 18 Kelurahan Sadang Serang, Kecamatan Coblong, Kota Bandung". Ini dikarenakan Kelurahan Sadang Serang merupakan wilayah rawan terhadap masalah penyalahgunaan NAPZA di Kecamatan Coblong, Kota Bandung.

\section{Rumusan Masalah}

Rumusan masalah dari penelitian ini adalah "Bagaimana Peningkatan Kontrol Sosial Masyarakat dalam Upaya Pencegahan Penyalahgunaan NAPZA di RW 18 Kelurahan Sadang Serang, Kecamatan Coblong, Kota Bandung”. Selanjutnya, untuk mendeskripsikan permasalahan penelitian tersebut peneliti perlu menjabarkan ke dalam sub permasalahan, yaitu: (1) Bagaimana karakteristik informan?, (2) Bagaimana kontrol sosial masyarakat dalam upaya pencegahan penyalahgunaan NAPZA?, (3) Bagaimana perencanaan model peningkatan kontrol sosial masyarakat dalam upaya pencegahan penyalahgunaan NAPZA?, (4) Bagaimana implementasi model peningkatan kontrol sosial masyarakat dalam upaya pencegahan penyalahgunaan NAPZA?, (5) Bagaimana model akhir peningkatan kontrol sosial masyarakat dalam upaya pencegahan penyalahgunaan NAPZA?

\section{Tujuan Penelitian}

Tujuandaripenelitianiniadalahmenghasilkan model yang tepat untuk peningkatan kontrol sosial masyarakat dalam upaya pencegahan penyalahgunaan NAPZA di RW 18 Kelurahan Sadang Serang. Tujuan khusus dari penelitian ini, yaitu: (1) Menggambarkan karakteristik informan, (2) Menggambarkan kontrol sosial masyarakat dalam upaya pencegahan penyalahgunaan NAPZA, (3) Merencanakan model peningkatan kontrol sosial masyarakat dalam upaya pencegahan penyalahgunaan NAPZA, (4) Mengimplementasikan model peningkatan kontrol sosial masyarakat dalam upaya pencegahan penyalahgunaan NAPZA, serta (5)
Merumuskan model akhir peningkatan kontrol sosial masyarakat dalam upaya pencegahan penyalahgunaan NAPZA.

\section{Manfaat Penelitian}

Manfaat teoritis dari penelitian ini, yaitu: (1) Memberikan masukan tentang model peningkatan kontrol sosial masyarakat dalam upaya pencegahan penyalahgunaan NAPZA, (2) Memberikan masukan tentang konsep pengembangan masyarakat lokal (locality development), serta (3) Memberikan sumbangan pemikiran tentang kemungkinan pengembangan kajian pekerjaan sosial dengan NAPZA. Penelitian ini diharapkan memberikan manfaat praktis, yaitu: (1) Meningkatkan kontrol sosial masyarakat dalam upaya pencegahan penyalahgunaan NAPZ, (2) Mendorong masyarakat untuk berpartisipasi dalam upaya pencegahan penyalahgunaan NAPZA, serta (3) Menyediakan informasi yang dapat menjadi dasar bagi semua pihak yang berkompeten dalam upaya pencegahan penyalahgunaan NAPZA.

\section{B. Kajian Pustaka \\ 1. Tinjauan Tentang Kontrol Sosial/
Pengendalian Sosial}

Menurut Siti Waridah Q. dan J. Sukardi (2003), "Pengendalian sosial adalah segenap cara dan proses yang ditempuh sekelompok orang atau masyarakat sehinggga para anggotanya dapat bertindak sesuai dengan harapan kelompok atau masyarakat". Pengendalian sosial berkaitan erat dengan norma dan nilai sosial. Bagi anggota masyarakat, norma sosial mengandung harapan yang dijadikan sebagai pedoman untuk berperilaku. Namun, masih ada sebagian kecil dari masyarakat yang menyimpang dari normanorma atau nilai-nilai yang berlaku. Agar masyarakat berperilaku sesuai dengan pedoman, pengendalian sosial merupakan mekanisme untuk mencegah terjadinya penyimpangan dan mengarahkan anggota masyarakat untuk bertindak menurut norma-norma dan nilai-nilai yang telah melembaga. 
Sementara itu menurut Sarjoeno Soekanto (2007), yang dimaksud "Pengendalian sosial adalah suatu proses baik yang direncanakan atau tidak direncanakan, yang bertujuan untuk mengajak, membimbing, atau bahkan memaksa warga masyarakat agar mematuhi nilai-nilai dan kaidah-kaidah yang berlaku". Pengendalian sosial meliputi proses sosial yang direncanakan maupun tidak direncanakan (spontan) untuk mengarahkan seseorang. Selain itu, pengendalian sosial pada dasarnya merupakan sistem dan proses yang mendidik, mengajak, dan bahkan memaksa warga masyarakat untuk berperilaku sesuai dengan norma-norma sosial. Sistem mendidik dimaksudkan agar dalam diri seseorang terdapat perubahan sikap dan tingkah laku untuk bertindak sesuai dengan norma-norma. Sistem mengajak bertujuan mengarahkan agar perbuatan seseorang didasarkan pada norma-norma, dan tidak menurut kemauan individu-individu. Sistem memaksa bertujuan untuk mempengaruhi secara tegas agar seseorang bertindak sesuai dengan norma-norma. Bila ia tidak mau menaati kaiah atau norma, maka ia akan dikenakan sanksi. Pengendalian sosial dimaksudkan agar anggota masyarakat mematuhi norma-norma sosial sehingga tercipta keselarasan dalam kehidupan sosial. Penggolongan pengendalian sosial dibuat menurut sudut pandang dari mana seseorang melihat pengawasan tersebut.

\section{Tinjauan Tentang Masyarakat}

Kata masyarakat berasal dari kata "musyaraka" (bahasa Arab) yang berarti peran serta. Pengertian masyarakat menurut Suharto (2009), "Masyarakat adalah sekelompok orang yang tinggal dan berinteraksi yang dibatasi oleh wilayah geografis tertentu seperti desa, kelurahan, kampung atau rukun tetangga".

Menurut Mayo (1998), masyarakat dapat diartikan dalam 2 konsep: (1) Masyarakat sebagai sebuah wadah "tempat bersama", yakni sebuah wilayah geografi yang sama. Sebagai contoh, sebuah rukun tetangga, perumahan di daerah perkotaan atau sebuah kampong di wilayah pedesaan, serta (2) Masyarakat sebagai "kepentingan bersama", yakni kesamaan kepentingan berdasarkan kebudayaan dan identitas. Sebuah contoh, kepentingan bersama pada masyarakat etnis minoritas atau kepentingan bersama berdasarkan identifikasi kebutuhan tertentu seperti halnya pada kasus para orang tua yang memiliki anak dengan kebutuhan khusus (anak cacat khusus) atau bekas para pengguna pelayanan kesehatan mental.

Masyarakat adalah suatu sistem kehidupan bersama yang terdiri dari sekumpulan kelompok manusia yang tinggal dalam suatu batas wilayah tertentu, memiliki tatanan kehidupan, normanorma, adat istiadat yang sama-sama ditaati dalam lingkungannya serta bekerja sama dan berinteraksi diantara anggota-anggota kelompok masyarakat tersebut.

\section{Tinjauan Tentang Masalah Penyalah- gunaan NAPZA}

Secara terminologi banyak istilah yang digunakan, yaitu NAPZA, Narkoba, Narkotika, Obat Terlarang, Zat Adiktif, Psikoaktif, Obat Bius, Madat, Drug, Medicine, dan lain-lainnya. Keseluruhannya terdapat kesamaan, yaitu addiction atau sesuatu yang dapat menyebabkan addict. Addiction merupakan segala sesuatu yang dapat menyebabkan ketagihan, kecanduan, dan dapat merusak sistem kerja pada otak. Sussman dan Ames (2008:3) menyatakan bahwa "A drug is a substance that can be taken into the human body, and once taken, alters some processes within the body. Drugs can be used in the diagnosis, prevention, or treatment of a disease (Obat adalah zat yang dapat dimasukan ke dalam tubuh manusia, dan setelah dimasukan, mengubah beberapa proses dalam tubuh. Obat dapat digunakan dalam diagnosis, pencegahan, atau pengobatan penyakit)".

Undang-Undang Republik Indonesia Nomor 35 Tahun 2009 tentang Narkotika menyatakan bahwa "Narkotika adalah zat atau obat yang berasal dari tanaman, baik sintesis maupun semisintetis, yang dapat menyebabkan penurunan atau perubahan kesadaran, hilangnya rasa, mengurangi sampai menghilangkan rasa 
nyeri, dan dapat menimbulkan ketergantungan, yang dibedakan ke dalam golongan-golongan sebagaimana terlampir dalam Undang-Undang ini”.

Lebih lanjut Undang-Undang Republik Indonesia Nomor 05 Tahun 1997 tentang Psikotropika menyatakan bahwa "Psikotropika adalah zat atau obat baik alami maupun sintetis bukan Narkotika yang berkhasiat psikoaktif yang menyebabkan perubahan khas pada aktivitas mental dan perilaku. Zat Adiktif merupakan zat bukan Narkotika atau Psikotropika yang berkhasiat adiktif, ketagihan psikis, dan fisik yang menyebabkan perubahan khas pada aktivitas mental dan perilaku".

Kementerian Sosial dan Kementerian Kesehatan menggunakan istilah NAPZA. NAPZA merupakan kependekan dari Narkotika, Psikotropika, dan Zat Adiktif Lainnya. Menurut Pasal 113 Ayat 2 Undang-Undang Republik Indonesia Nomor 36 Tahun 2009 tentang Kesehatan, istilah NAPZA hanya terbatas pada istilah Zat Adiktif. Zat Adiktif sebagaimana dimaksud meliputi tembakau, produk yang mengandung tembakau, padat, cairan, dan gas yang bersifat adiktif yang penggunaannya dapat menimbulkan kerugian bagi dirinya dan/atau masyarakat sekelilingnya.

\section{Praktik Pekerjaan Sosial dalam Masalah Penyalahgunaan NAPZA}

Hakekat pekerjaan sosial dalam masalah penyalahgunaan NAPZA adalah memberikan pertolongan kepada individu maupun kolektifitas (kelompok atau masyarakat) yang bertujuan untuk membantu mereka agar dapat menjalankan fungsi sosialnya secara wajar sesuai peranannya dalam kehidupan masyarakat. Pemberdayaan dan partisipasi masyarakat merupakan hal yang menjadi pusat perhatiannya. Pemberdayaan juga menyangkut strategi nasional dalam upaya penanganan penyalahgunaan NAPZA, serta peredaran gelap NAPZA. International Federation of Social Work (dalam Tan dan Enval, 2000:5) menyatakan bahwa "The social work profession promotes problem solving in human relationships, social change, empowerment and liberation of people, and the enhancement of society. Utilizing theories of human behavior and social systems, social work intervenes at the points where people interact with their environments. Principles of human rights and social justice are fundamental to social work (Profesi pekerjaan sosial mendorong pemecahan masalah dalam kaitannya dengan relasi kemanusiaan, perubahan sosial, pemberdayaan dan pembebasan manusia, serta perbaikan masyarakat. Menggunakan teori-teori perilaku manusia dan sistem-sistem sosial, pekerjaan sosial melakukan intervensi pada titik dimana seseorang berinteraksi dengan lingkungannya. Prinsip-prinsip hak asasi manusia dan keadilan sosial sangat penting bagi pekerjaan sosial)".

Pekerjaan sosial makro atau juga disebut dengan community practice adalah aplikasi keterampilan praktik untuk merubah polapola tingkah laku dari komunitas kelompok, organisasi, serta institusi atau hubungan orangorang dan interaksinya dengan entitas-entitas ini. Menurut Adi (2008:115-116) terdapat beberapa istilah yang digunakan dalam ilmu kesejahteraan sosial terkait dengan pembahasan tentang pembangunan sosial dan pemberdayaan masyarakat, yaitu: (1) Community Work, istilah ini merupakan terminologi untuk praktik pengorganisasian dan pengembangan masyarakat yang banyak digunakan di Inggris dan Australia, seperti yang digunakan oleh Thrope (1985), Mayo (1994), Popple (1995), dan Jones (1997), (2) Community Organization, terminologi ini digunakan oleh Rothman, Tropman, dan Erlich sejak tahun 1960-an hingga 1987-an (terminologi yang banyak digunakan di Amerika Serikat), sedangkan dari edisi kelima buku Community Organization, Rothman (1995) telah mengubah nama dari intervensi ini menjadi community intervention (intervensi komunitas), (3) Di Indonesia, terminologi yang banyak digunakan pada dasawarsa 1970-1990-an adalah pengorganisasian dan pengembangan masyarakat. Istilah intervensi komunitas adalah istilah yang relatif baru dikembangkan sekitar tahun 2000-an 
merespons perubahan dari istilah yang digunakan oleh Rothman, serta (4) Di samping itu, Glen (1993) menggunakan istilah yang berbeda, yaitu community practice (praktik komunitas) untuk menggambarkan model intervensi yang serupa dengan apa yang dikemukakan oleh Rothman dalam intervensi komunitas.

\section{Metode Penelitian}

\section{Desain, Waktu, dan Lokasi Penelitian}

Metode yang digunakan dalam penelitian ini adalah metode penelitian kualitatif. Sugiyono (2014:1) menyatakan bahwa "Metode penelitian kualitatif adalah metode penelitian yang digunakan untuk meneliti pada kondisi obyek yang alamiah, (sebagai lawannya adalah eksperimen) dimana peneliti adalah sebagai instrumen kunci, teknik pengumpulan data dilakukan secara triangulasi (gabungan), analisis data bersifat induktif, dan hasil penelitian kualitatif lebih menekankan makna daripada generalisasi". Adapun jenis penelitian yang digunakan adalah penelitian tindakan (action research). Penelitian tindakan merupakan salah satu varian dari penelitian terapan (applied research) dan termasuk dalam penelitian evaluasi (evaluation research) yang dimaksudkan untuk mendekatkan atau menghilangkan batasan antara teori dan praktik.

Waktu yang dibutuhkan dalam penelitian ini adalah tanggal 01 Juli 2015 sampai dengan 02 November 2015. Lokasi yang digunakan dalam penelitian ini adalah RW 18 Kelurahan Sadang Serang, Kecamatan Coblong, Kota Bandung. Lokasi tersebut merupakan salah satu wilayah yang rentan terhadap masalah penyalahgunaan NAPZA. Penelitian berfokus pada peningkatan kontrol sosial masyarakat dalam upaya pencegahan penyalahgunaan NAPZA.

\section{Jenis dan Sumber Data}

Pengumpulan data dapat dilakukan dalam berbagai setting, sumber, dan cara. Jenis data yang digunakan dalam penelitian ini, yaitu: (1) Kata dan tindakan dari informan yang dipilih secara acak, disesuaikan dengan informasi yang dibutuhkan, dan lebih diarahkan kepada stakeholders dan masyarakat RW 18 Kelurahan Sadang Serang. Hal ini berkaitan dengan pelaksanaan model awal dan langkah-langkah yang perlu diambil untuk melakukan peningkatan kontrol sosial masyarakat dalam upaya pencegahan penyalahgunaan NAPZA, (2) Dokumen tertulis yang terdiri atas buku-buku laporan dan dokumen foto terkait dengan kegiatan dalam upaya pencegahan penyalahgunaan NAPZA, serta (3) Data statistik yang berkaitan dengan kegiatan dalam upaya pencegahan penyalahgunaan NAPZA yang memerlukan perhitungan angka sebagai data tambahan.

Sumber datayang digunakan dalam penelitian ini adalah sumber data primer dan sumber data sekunder. Menurut Sugiyono (2014:62) "Sumber data primer adalah sumber data yang langsung memberikan data kepada pengumpul data". Sumber data primer merupakan sumber data atau informasi yang diperoleh langsung dari informan atau partisipan yang telah ditetapkan. Sumber data primer dalam penelitian ini adalah stakeholders dan masyarakat RW 18 Kelurahan Sadang Serang. Informan pendukung dalam penelitian ini berasal dari instansi terkait berjumlah 2 orang. Karakteristik yang akan dijadikan informan dalam penelitian ini, yaitu informan yang berpendidikan minimal SLTA, informan yang telah merasakan program pencegahan penyalahgunaan NAPZA, dan informan yang tidak lagi menyalahgunakan NAPZA. Menurut Sugiyono (2014:62) "Sumber data sekunder merupakan sumber data yang tidak langsung memberikan data kepada pengumpul data misalnya lewat orang lain atau lewat dokumen". Sumber data sekunder, yaitu sumber data penunjang yang diperolah dari berbagai pihak. Contohnya adalah masyarakat, Ketua RW, Ketua RT, Tokoh Agama, Tokoh Masyarakat, Ketua Karang Taruna, Kader PKK, Kader Posyandu, Kader RBM, Tenaga Kerja Sosial Kecamatan, Pegawai Puskesmas Puter, Pekerja Sosial Masyarakat, LPM Kelurahan, Koordinator BKM Paguyuban Amanah, Aparat Kelurahan Sadang Serang, Lembaga Swadaya Masyarakat, 
serta lembaga atau instansi yang terkait. Sumber data sekunder juga dapat berupa catatan, laporan hasil penelitian, buku-buku pedoman, dan literatur lain yang dianggap relevan dengan penelitian.

Pada penelitian ini, teknik yang digunakan dalam menentukan informan adalah purposive sampling. Menurut Sugiyono (2014:53-54) "Purposive sampling adalah teknik pengambilan sampel sebagai sumber data dengan pertimbangan tertentu. Pertimbangan tertentu ini, misalnya orang tersebut yang dianggap paling tahu tentang apa yang kita harapkan, atau mungkin dia sebagai penguasa sehingga akan memudahkan peneliti menjelajahi obyek/situasi sosial yang diteliti”. Penentuan sampel ini dilakukan setelah peneliti mulai memasuki lapangan dan selama penelitian berlangsung (emergent sampling design). Caranya dengan mempertimbangkan orang yang dapat memberikan data, yaitu orang-orang yang terlibat langsung pada proses pelaksanaan model awal. Selanjutnya, berdasarkan informasi dari sampel ini peneliti menetapkan sampel lainnya yang akan memberikan data lebih lengkap.

\section{Teknik Pengumpulan Data}

Teknik pengumpulan data yang digunakan dalam penelitian ini adalah wawancara mendalam, observasi partisipatif, studi dokumnetasi, FGD (Focus Gorup Discussion), ToP (Tecnology of Participation), dan PEKA (Penilaian Kapasitas). Menurut Esterberg, 2002 (dalam Sugiyono, 2014:72) "A meeting of two persons to exchange information and idea through question and meaning about a particular topic (Wawancara adalah merupakan pertemuan dua orang untuk bertukar informasi dan ide melalui tanya jawab, sehingga dapat dikonstruksikan makna dalam suatu topik tertentu)".Wawancara mendalam dilakukan dengan cara mengajukan sejumlah pertanyaan yang telah disusun secara sistematis dalam pedoman wawancara mendalam. Pedoman wawancara mendalam berguna sebagai alat kontrol agar pertanyaan yang diajukan sesuai dengan fokus penelitian. Wawancara mendalam dilakukan kepada 1 orang informan utama, kemudian informan ini menunjuk informan lainnya yang dianggap lebih mengetahui dan memahami tentang maslah penyalahgunaan NAPZA. Peneliti juga ingin memperoleh gambaran tentang hambatan-hambatan yang mereka rasakan selama mengikuti pelaksanaan kegiatan.

Menurut Sugiyono (2014:64) "Dalam Observasi partisipatif, peneliti terlibat dengan kegiatan sehari-hari orang yang sedang diamati atau yang digunakan sebagai sumber data penelitian". Lebih lanjut menurut Stainback, 1988 (dalam Sugiyono, 2014:65) "In participant observation, researcher observes what people do, listen to what they say, and participates in their activities (Dalam obervasi partisipatif, peneliti mengamati apa yang dikerjakan orang, mendengar apa yang mereka ucapkan, dan berpartisipasi dalam aktivitas mereka)". Observasi Partisipatif, dilakukan pada saat penelitian dengan memanfaatkan informasi dari informan tentang adanya kegiatan-kegiatan masyarakat yang berkaitan dengan fokus penelitian. Observasi partisipatif merupakan bentuk keterlibatan langsung dengan kegiatan masyarakat yang sedang diamati atau yang digunakan sebagai sumber data penelitian. Melalui observasi partisipatif ini dilakukan pelibatan diri ke dalam lingkungan mereka, sehingga data yang diperoleh lebih lengkap, tajam, dan sampai mengetahui pada tingkat makna dari setiap perilaku yang tampak.

Studi Dokumentasi merupakan suatu teknik yang digunakan untuk mendapatkan data sekunder. Dokumentasi dapat berupa catatan peristiwa yang telah berlalu dalam bentuk tulisan, gambar, atau kegiatan masyarakat. Hal ini dilakukan dengan cara membaca dan mempelajari berbagai sumber data sekunder yang berkaitan dengan aspek penelitian, yaitu dokumentasi dan data tentang berbagai program pencegahan penyalahgunaan NAPZA baik dari pemerintah maupun nonpemerintah.

FGD (Focus Group Discussion), teknik pengumpulan data dalam menemukan makna sebuah tema secara terarah. FGD dalam penelitian ini dilakukan dengan melibatkan stakeholders dan masyarakat RW 18 Kelurahan Sadang 
Serang. FGD dilakukan dengan cara menggali data dan informasi tentang suatu permasalahan tertentu secara spesifik melalui diskusi kelompok. Tujuannya untuk menggali partisipasi semua partisipan, dimana dalam diskusi mempunyai kesamaan kesempatan untuk mengemukakan tanggapan dan masukan dalam rangka menangani masalah tersebut. Diskusi kelompok dalam hal ini, yaitu pertemuan kelompok yang telah direncanakan maupun tidak direncanakan. Diskusi yang tidak direncanakan sasarannya adalah informan yang tidak terlibat langsung pada pelaksanaan setiap proses model awal dengan memanfaatkan momen tertentu. Hal ini dilakukan pada saat masyarakat berkumpul dan terlibat dalam pembicaraan suatu permasalahan. Diskusi yang telah direncanakan merupakan diskusi yang dilakukan saat pertemuan masyarakat dengan menggunakan teknik FGD. Diskusi ini dirancang dalam pertemuan masyarakat dengan sasarannya adalah partisipan yang terlibat langsung dalam kegiatan awal pada saat penelitian terdahulu.

ToP (Tecnology of Participation), teknik yang digunakan dalam menyusun rencana tindak bersama-sama dengan masyarakat secara partisipatif. Suatu metode fasilitasi dalam pembuatan keputusan yang tujuannya untuk mengeksplorasi munculnya inisiatif, sikap kepemimpinan, keputusan, dan tanggungjawab dari seluruh masyarakat. Tahapan dalam menyusun rencana tindak, yaitu nama kegiatan, tujuan kegiatan, sasaran kegiatan, pembentukan TKM (Tim Kerja Masyarakat), metode dan teknik, strategi dan taktik, prinsip, mekanisme kerja, pengorganisasian, langkah-langkah kegiatan, pelaksana kegiatan, peran peneliti, rincian kegiatan, rencana anggaran biaya, indikator keberhasilan, serta analisis SWOT.

\section{Teknik Analisis Data}

Teknik analisi data yang digunakan dalam penelitian ini adalah teknik analisis kualitatif dengan model teknik analisis interkatif, meliputi: reduksi data, display data, dan penarikan kesimpulan.
Menurut Madya (2011:76) "Reduksi data merupakan proses menyeleksi, menentukan fokus, menyederhanaan, meringkas, dan mengubah bentuk data mentah yang ada dalam catatan lapangan". Pada proses reduksi data peneliti akan melakukan penajaman, pemilahan, pemfokusan, penyisihan data yang kurang bermakna, dan menatanya sedemikian rupa sehingga mendapatkan kesimpulan akhir melalui penarikan dan verifikasi.

Menurut Madya (2011:78) "Setelah direduksi data siap dibeberkan. Artinya, tahap analisis sampai pada pemeberan data. Berbagai macam data penelitian tindakan yang telah direduksi perlu dibeberkan dengan tertata rapi dalam bentuk narasi plus matriks, grafik, dan/atau diagram". Display data dilakukan setelah mendapatkan hasil reduksi data. Bentuk display data akan ditata rapi dalam bentuk narasi dengan ditambahkan matriks, grafik, atau diagram secara sistematik, interaktif, inventif, dan mantap. Tujuannya untuk memudahkan pemahaman terhadap apa yang telah terjadi, sehingga memudahkan penarikan kesimpulan atau penentuan tindakan yang akan dilakukan selanjutnya.

Menurut Madya (2011:78) "Penarikan kesimpulan dilakukan secara bertahap mulai dari kesimpulan sementara, yang ditarik pada akhir Siklus I, ke kesimpulan terevisi pada akhir Siklus II, dan seterusnya, dan kesimpulan terakhir pada akhir Siklus trakhir". Penarikan Kesimpulan dilakukan setelah pendisplayan data. Tahapan penarikan kesimpulan dimulai dari penarikan kesimpulan pada saat asesmen awal, kesimpulan yang terevisi, dan kesimpulan akhir implementasi kegiatan. Kesimpulan asesmen awal akan dijadikan sebagai pijakan untuk melangkah kepada pelaksanaan kegiatan. Kesimpulan yang dibuat mencakup semua perubahan/peningkatan yang direncanakan/diharapkan dan yang tidak diharapkan.

\section{Teknik Pemeriksaan Keabsahan Data}

Teknik pemeriksaan keabsahan data atau kevalidan data yang digunakan dalam penelitian ini adalah uji kredibiltas, uji transferability/ 
validitas eksternal, dan uji dependability/ reliabilitas.

Menurut Stainback, 1988 (dalam Sugiyono, 2014:123) "Rapport is a relationship of mutual trust and emotional affinity between two or more people (Kesesuaian adalah hubungan saling percaya dan persamaan emosional antara dua orang atau lebih)". Perpanjangan pengamatan akan peneliti lakukan dengan kembali ke lokasi penelitian untuk melakukan wawancara mendalam dan pengamatan terhadap informan pada saat penelitian terdahulu maupun penelitian. Perpanjangan pengamatan akan memudahkan peneliti selama proses penelitian. Menurut Sugiyono (2014:124) "Meningkatkan ketekunan berarti melakukan pengamatan secara lebih cermat dan berkesinambungan". Peneliti akan meningkatkan ketekunan dengan melakukan kembali pengamatan secara lebih cermat, tepat, dan berkesinambungan kepada stakeholders dan masyarakat RW 18 Kelurahan Sadang Serang, serta pihak lain yang dilibatkan dalam penelitian. Menurut Wiersma, 1986 (dalam Sugiyono, 2014:125-128) "Triangulation is qualitative cross-validation. It assesses the sufficiency of the data according to the convergence of multiple data sources or multiple data collection procedures (Triangulasi adalah lintasan kualitatif-validasi. Itu menilai kecukupan data sesuai dengan konvergensi berbagai sumber data atau prosedur beberapa pengumpulan data)". Triangulasi merupakan teknik pemeriksaan keabsahan data yang memanfaatkan sesuatu yang lain di luar data. Tujuannya untuk kepentingan pengecekan atau sebagai pembanding terhadap data tersebut. Triangulasi terbagi menjadi tiga, yaitu sumber, teknik, dan waktu. Jenis triangulasi yang akan digunakan adalah teknik pemeriksaan yang memanfaatkan sumber. Teknik triangulasi akan dicapai melalui perbandingan data hasil pengamatan dengan hasil wawancara mendalam, membandingkan apa yang dikatakan stakeholders dan masyarakat RW 18 Kelurahan Sadang Serang di depan umum dengan apa yang dikatakannya secara pribadi, membandingkan apa yang dikatakan stakeholders dan masyarakat
RW 18 Kelurahan Sadang Serang tentang situasi penelitian dengan apa dikatakannya sepanjang waktu, dan membandingkan hasil wawancara mendalam dan FGD dengan hasil observasi partisipatif dan studi dokumentasi. Peneliti menggunakan alat pendukung untuk membuktikan data yang ditemukan melalui wawancara mendalam, foto, rekaman, dan video.

Menurut Sugiyono (2014:130) "Validitas eksternal menunjukkan derajad ketepatan atau dapat diterapkannya hasil penelitian ke populasi dimana sampel tersebut diambil". Peneliti akan berupaya memberikan gambaran utuh tentang laporan peningkatan kontrol sosial masyarakat dalam upaya pencegahan penyalahgunaan NAPZA di RW 18 Kelurahan Sadang Serang secara jelas, terperinci, sistematis, dan dipercaya. Tujuannya agar pembaca dapat dengan mudah menangkap apa yang dituliskan oleh peneliti dan kemungkinan untuk menerapkan hasil penelitian ini di tempat lain dengan karakteristik yang sama.

Menurut Sugiyono (2014:131) "Suatu penelitian yang reliabel adalah apabila orang lain dapat mengulangi/mereplikasi proses penelitian tersebut". Uji reliabilitas dilakukan oleh auditor independen. Auditor independen dalam penelitian ini adalah dosen pembimbing penelitian. Tujuannya untuk mengaudit keseluruhan aktivitas penelitian dengan menunjukkan masalah, sumber data, keabsahan data, dan kesimpulan dari hasil penelitian yang jelas.

\section{Tahapan Penelitian}

Penelitian diawali dengan kegiatan pra lapangan untuk pengumpulan data sebagai kelengkapan data dalam penyusunan proposal penelitian. Hasil pembuatan proposal dilanjutkan dengan seminar proposal penelitian sehingga mendapat tanggapan dan masukan guna pelaksanaan penelitian, sekaligus pengajuan instrumen penelitian. Setelah melakukan revisi terhadap kelayakan proposal penelitian dan instrumen penelitian, tahapan selanjutnya adalah pengurusan ijin penelitian. Pelaksanaan penelitian dilakukan dengan tahapan persiapan sosial, refleksi awal, pengumpulan, pemeriksaan dan analisis data, 
perencanaan model, implemetasi model, serta refleksi akhir. Akhir dari tahapan penelitian adalah penyusunan dan bimbingan Karya Ilmiah Kompetensi Akhir (KIKA), yang dilanjutkan dengan ujian lisan Karya Ilmiah Kompetensi Akhir (KIKA).

\section{Hasil Penelitian dan Pembahasan}

\section{Karakteristik Informan}

Penelitian tentang peningkatan kontrol sosial masyarakat dalam upaya pencegahan penyalahgunaan NAPZA di RW 18 Kelurahan Sadang Serang dilakukan peneliti bersama dengan beberapa informan yang dianggap dapat memberikan informasi yang dibutuhkan. Pemilihan informan tersebut didasarkan pada kriteria yang menjadi stakeholders dan masyarakat RW 18 Kelurahan Sadang Serang.

Jumlah informan penelitian sebanyak 8 orang, yaitu 6 orang untuk analisis masalah, kebutuhan dan potensi, serta 3 orang untuk perencanaan model intervensi. Informan analisis masalah, kebutuhan dan potensi, korban penyalahgunaan NAPZA, tokoh pemuda, tokoh masyarakat, tokoh agama, Ketua RW, serta Sekretaris Lurah Sadang Serang. Informan untuk perencanaan model intervensi, meliputi BNN (Badan Narkotika Nasional) Kota Bandung, BNN (Badan Narkotika Nasional) Provinsi Jawa Barat, dan Satuan Reserse Narkoba Kepolisian Resort Kota Besar Bandung. Informan berusia antara 18 sampai dengan 60 tahun dengan jenis pekerjaan yang beragam, yaitu pelajar, karyawan swasta, wiraswasta, Ketua RW, Pensiunan, PNS (Pegawai Negeri Sipil), dan Aparat Kepolisian. Tingkat pendidikan yang dimiliki informan berbeda, pendidikan terendah lulusan SMP dan pendidikan tertinggi lulusan S2. Hal ini menandakan bahwa tingkat pendidikan pengurus dan anggota cukup baik untuk dikembangkan dalam mengelola organisasi lokal "Pemuda Anti NAPZA".

\section{Gambaran Kontrol Sosial Masyarkat}

Setelah proses persiapan sosial dilakukan, peneliti kemudian memulai kegiatan asesmen. Asesmen merupakan kegiatan untuk memperoleh profil lengkap tentang situasi dan kondisi lapangan (agency based maupun community based research), serta mengungkap masalah, kebutuhan, serta potensi dan sumber secara umum. Asesmen dilakukan melalui wawancara mendalam, observasi partisipatif, dan studi dokumentasi. Asesmen bertujuan untuk menggali, menganalisis, dan mengungkapkan isu-isu permasalahan, kebutuhan, serta potensi dan sumber yang melekat di dalam masyarakat RW 18 Kelurahan Sadang Serang. Asesmen dilakukan secara partisipatif dan non-partisipatif dengan harapan dapat memperoleh data, informasi, dan masukan secara langsung dari masyarakat RW 18 Kelurahan Sadang Serang. Data, informasi, dan masukan akan sangat bermanfaat bagi peneliti untuk menentukan tahapan selanjutnya. Dalam melakukan asesmen, peneliti tentunya tidak melakukannya secara langsung. Hal ini untuk menghindari ketidaktepatan dan efisiensi dalam melakukannya.

Data yang diperoleh dari hasil wawancara di lapangan, peneliti menemukan beberapa masalah penyalahgunaan NAPZA, yaitu: merokok, mengkonsumsi minuman alkohol, dan menggunakan NAPZA jenis lainnya. Merokok biasanya dilakukan oleh para anak-anak atau remaja, sedangkan mengkonsumsi minuman alkohol paling banyak dilakukan oleh orang dewasa. Lokasi rentan yang menjadi tempat melakukan penyalahgunaan NAPZA biasanya terjadi pada tempat-tempat yang terbuka, yaitu: lapangan badminton, pos hansip, warung, maupun rumah masyarakat. Lokasi tersebut berada di wilayah RT 01, RT 03, RT 04, RT 05, dan RT 06.

Faktor penyebab masyarakat menyalahgunakan NAPZA terutama karena faktor lingkungan. Pengaruh lingkungan yang dimaksud, yaitu: masyarakat sering nongkrong, adanya kegiatan perjudian, dan pengaruh masyarakat luar wilayah RW 18 Kelurahan Sadang Serang. Mudahnya mendapatkan rokok dan minuman alkohol juga merupakan faktor penyebab lainnya 
dari masalah penyalahgunaan NAPZA. Selain mengakibatkan gangguan fisik dan psikologis, masalah penyalahgunaan NAPZA juga dapat berpengaruh pada lingkungan. Hal ini dikarenakan dapat mengganggu kenyamanan dan ketentraman hidup masyarakat. Masalah penyalahgunaan NAPZA juga dapat menimbulkan permasalahan baru, yaitu munculnya masalah kriminalitas dan kebobrokan mental dari generasi muda. Akan tetapi, rasa kepedulian dan kontrol masyarakat sangatlah kurang. Hal ini ditandai dengan jarangnya masyarakat menegur penyalahguna NAPZA dan seolah-olah membiarkan penyalahguna untuk merokok, mengkonsumsi minuman alkohol, dan menggunakan NAPZA jenis lainnya.

Masalah penyalahgunaan NAPZA di RT 01, RT 03, RT 04, RT 05, dan RT 06 (paku putih). Masalah penyalahgunaan NAPZA di RT 01 adalah merokok dan mengkonsumsi minuman alkohol yang mereka lakukan di pos hansip yang mereka gunakan untuk nongkrong sambil. Masalah penyalahgunaan NAPZA di RT 03 adalah merokok, mengkonsumsi minuman alkohol, bahkan berjudi di rumah salah satu masyarakat. Masalah penyalahgunaan NAPZA di RT 04 adalah merokok da mengkonsumsi minuman alkohol di sebuah warung yang buka hingga larut malam. Salah satu masyarakat RT 04 yang terlibat kasus penyalahgunaan NAPZA, yaitu adik dari Bapak RW yang ditangkap karena kasus ganja. Masalah penyalahgunaan NAPZA di RT 05 adalah merokok, mengkonsumsi minuman alkohol, bahkan berjudi di rumah salah satu masyarakat. Beberapa kasus masalah penyalahgunaan NAPZA yang terjadi di RT 05 lainnya, yaitu: masyarakat RT 05 yang juga ditangkap karena kasus shabu-shabu, masyarakat RT 05 yang masih menggunakan obatobatan terlarang, dan adanya 1 orang mantan narapidana kasus penyalahgunaan NAPZA. Masalah penyalahgunaan NAPZA di RT 06 adalah merokok dan mengkonsumsi minuman alkohol yang mereka lakukan di lapangan badminton. Lapangan ini sering digunakan untuk memperingati acara besar RW 18 Kelurahan Sadang Serang. Akan tetapi, setelah acara tersebut berakhir, masyarakat mulai menyalahgunakan NAPZA.

Hasil identifikasi terhadap kontrol sosial masyarakat melalui wawancara mendalam, observasi partisipatif dan studi dokumentasi kemudian disandingkan dan diuji dengan datadata yang diperoleh melalui FGD (Focus Group Discussion). Melalui FGD banyak partisipan menyampaikan pendapatnya tentang bagaimana kondisi, dan situasi kontrol sosial masyarakat. Terdapat beberapa permasalah NAPZA yang terjadi di RW 18 Kelurahan Sadang Serang, diantaranya: (1) Merokok, (2) Minuman alkohol, (3) Penggunaan NAPZA jenis lainnya, (4) Kurangnya keimanan dan kesadaran seseorang terhadap masalah penyalahgunaan NAPZA, (5) Kurangnya pengetahuan dan pemahaman masyarakat terhadap masalah penyalahgunaan NAPZA, serta (6) Kurangnya kontrol sosial masyarakat terhadap masalah penyalahgunaan NAPZA.

Informan mengemukakan beberapa faktor penyebab dan Akibat masyarakat menggunakan NAPZA di RW 18 Kelurahan Sadang Serang dengan menggunakan metode FGD (Focus Group Discussion). Faktor penyebab dari masalah penyalahgunaan NAPZA di RW 18 Kelurahan Sadang Serang menurut masyarakat, yaitu: (1) Pengaruh dari luar masyarakat RW 18 Kelurahan Sadang Serang yang sering ikut nongkrong, (2) Sosialisasi tentang bahaya penyalahgunaan NAPZA belum pernah dilakuka, (3) Masyarakat kurang memahami dan mengetahui terhadap masalah penyalahgunaan NAPZA, (4) Keluarga (orang tua) kurang mengawasi remaja yang sering merokok dan mengkonsumsi minuman alkohol, serta (5) Tokoh masyarakat kurang memperhatikan upaya pencegahan terhadap masalah penyalahgunaan NAPZA kepada warganya. Prioritas penyebab masalah penyalahgunaan NAPZA di RW 18 Kelurahan Sadang Serang adalah kurangnya perhatian tokoh masyarakat untuk mencegah masalah penyalahgunaan NAPZA kepada warganya.

Akibat dari masalah penyalahgunaan NAPZA di RW 18 Kelurahan Sadang Serang 
menurut masyarakat, yaitu: (1) Menimbulkan masalah kriminal dan perilaku negatif lainnya, (2) Menimbulkan kebobrokan mental dari generasi muda, (3) Mengganggu kenyamanan dan ketentraman hidup masyarakat, Masyarakat yang menjadi pelaku menjadi tidak memiliki kemampuan memecahkan masalah hidupnya, karena NAPZA dijadikan salah satu solusi untuk memecahkan masalahnya, serta (5) Meningkatkan jumlah penyalahguna NAPZA. Akibat utama dari masalah penyalahgunaan NAPZA berdasarkan hasil partisipasi masyarakat adalah meningkatnya jumlah penyalahguna NAPZA di RW 18 Kelurahan Sadang Serang.

Upaya pencegahan penyalahgunaan NAPZA yang ada RW 18 Kelurahan Sadang Serang tidak terlepas dari potensi dan sumber yang tersedia di wilayah tersebut. Diperoleh gambaran berkaitan dengan potensi dan sumber yang dimiliki dan dapat dimanfaatkan oleh masyarakat dalam menyelesaikan masalah penyalahgunaan NAPZA, yaitu: (1) Sumber formal yaitu sistem sumber yang dibentuk oleh pemerintah, yaitu: Dinas Sosial Kota Bandung, Badan Narkotika Kota Bandung, Kantor Kecamatan Coblong, Polisi Sektor Kecamatan Coblong, TKSK (Tenaga Kerja Sosial Kecamatan) Kecamatan Coblong, PSM (Pendamping Sosial Masyarakat) Kelurahan Sadang Serang, Kantor Kelurahan Sadang Serang, LPM Kelurahan Sadang Serang, BKM Paguyuban Amanah Kelurahan Sadang Serang, dan IPWL (Institusi Penerima Wajib Lapor), (2) Sistem sumber informal bersifat alamiah yang dapat dimanfaatkan dalam upaya pencegahan penyalahgunaan NAPZA, yaitu: berupa dukungan emosional, kasih sayang, perhatian keluarga, serta kearifan lokal yang masih melekat pada masyarakat RW 18 Kelurahan Sadang Serang, yaitu: Ketua RW, Ketua RT, Tokoh Agama, Tokoh Masyarakat, Karang Taruna, Kader PKK, dan Kader Posyandu, Brigadir RW, serta nilai kebersamaan dan gotong royong, (3) Sistem sumber kelembagaan, yaitu kelembagaan lokal yang dapat dimanfaatkan dan dipergunakan sebagai media dalam upaya pencegahan penyalahgunaan NAPZA di RW
18 Kelurahan Sadang Serang, yaitu: PKK, Posyandu, DKM, dan Karang Taruna. Sumbersumber tersebut dapat dimanfaatkan dalam upaya pencegahan penyalahgunaan NAPZA, serta (4) Sistem sumber daya manusia, yaitu adanya stakeholders yang memiliki kepedulian terhadap upaya pencegahan penyalahgunaan NAPZA. Hal ini bisa terlihat dari setiap pertemuan yang diselenggarakan oleh peneliti, masyarakat RW 18 Kelurahan Sadang Serang sangat antusias dan ikut terlibat serta hadir dalam setiap pertemuan.

\section{Gambaran Perencanaan Model Peningkatan Kontrol Sosial Masyarakat}

Penyusunan perencanaan model intervensi adalah salah satu tahapan kegiatan yang perlu dilakukan dalam penelitian. Perencanaan model intervensi merupakan aktivitas mutlak yang harus dilakukan, dikarenakan tidak terpisahkan dalam suatu sistem pelayanan sosial. Melalui perencanaan model intervensi dapat tersusun jenis, tujuan, dan langkah-langkah kegiatan yang akan dilakukan dalam upaya pencegahan penyalahgunaan NAPZA di RW 18 Kelurahan Sadang Serang.

Model atau teknik yang peneliti gunakan dalam menyusun perencanaan model intervensi adalah ToP (Tecnology of Participation). ToP adalah teknik yang digunakan dalam menyusun rencana tindak bersama-sama dengan masyarakat secara partisipatif. Suatu metode fasilitasi dalam pembuatan keputusan yang tujuannya untuk mengeksplorasi munculnya inisiatifinisiatif, sikap kepemimpinan, keputusan, dan tanggung jawab dari seluruh masyarakat. Semua pihak yang terlibat dalam pertemuan memiliki kesempatan sama untuk menyampaikan gagasan dan menolong setiap orang. Posisi peneliti dalam perencanaan model intervensi hanya sebagai pendamping atau fasilitator dalam mempersiapkan dan menyusun perencanaan. Tujuan yang ingin dicapai melalui perencanaan model intervensi yang bersifat partisipatif, yaitu: (1) Perencanaan partisipastif dapat membuka peluang kepada semua pihak yang terlibat secara langsung maupun tidak langsung untuk 
berpartisipasi, agar masyarakat dapat memahami, merasa memiliki, dan bertanggung jawab dalam menyukseskan kegiatan, (2) Memberikan peluang seluas-luasnya kepada masyarakat untuk menyampaikan ide-ide dan inisiatifnya dalam upaya mengadakan perubahan bersama secara lebih terarah dan terorganisir, serta sesuai dengan kondisi dan kebutuhannya, (3) Menciptakan kerangka kerja secara bersama dan dilaksanakan oleh semua masyarakat, sehingga masyarakat sebagai obyek dan subyek pembangunan dapat tercapai, serta (4) Hasil perencanaan bersifat kontekstual, aktual, serta spesifik, sehingga benar-benar dapat menggambarkan permasalahan dan kebutuhan. Masyarakat akan memiliki keterampilan dan kemampuan untuk menangani persoalannya (self help).

Aktivitas awal yang dilakukan pada tahap ini adalah peneliti terlebih dahulu melakukan koordinasi atau diskusi. Disepakati dalam diskusi tersebut agar peneliti terlebih dahulu mensosialisasikan hasil analisis masalah, kebutuhan, dan potensi sebagai informasi awal sebelum melakukan pertemuan untuk menyusun perencanaan model intervensi. Tujuannya agar masyarakat mengetahui dan memahami tentang berbagai masalah, kebutuhan, serta potensi yang tersedia. Selain itu juga, untuk menyampaikan rencana pembentukan TKM yang akan bekerja untuk memfasilitasi upaya pencegahan penyalahgunaan NAPZA di RW 18 Kelurahan Sadang Serang.

Pembentukan TKM dilaksanakan bertepatan dengan kegiatan sosialisasi hasil analisis masalah, kebutuhan, dan potensi. Proses pembentukan TKM ini memberikan kekuatan dan perasaan optimis bagi peneliti. Hal ini dikarenakan, semangat TKM menunjukan adanya kemauan yang kuat untuk belajar dan berbuat sesuatu bagi komunitasnya, terutama dalam upaya pencegahan penyalahgunaan NAPZA di RW 18 Kelurahan Sadang Serang.

Untuk persiapan dalam menyusun perencanaan model intervensi, maka terlebih dahulu peneliti bersama dengan TKM melakukan konsultasi. Pelaksanaan konsultasi melibatkan pihak yang berkompeten, meliputi BNN (Badan Narkotika Nasional) Kota Bandung dan BNN (Badan Narkotika Nasional) Kota Bandung. Tujuannya untuk mengetahui pandangan mereka tentang upaya pencegahan penyalahgunaan NAPZA di RW 18 Kelurahan Sadang Serang yang akan direncanakan dan dilaksanakan bersamasama dengan TKM. Selain itu juga, peneliti bersama dengan kepengurusan TKM melakukan identifikasi terhadap kemampuan finansial dan sumber daya manusia, serta kesediaan keluarga dan masyarakat untuk ikut memberikan konstribusi implementasi model intervensi.

Peneliti terlebih dahulu menawarkan kepada partisipan pertemuan untuk membuat rencana pemecahan masalah yang didasarkan pada kekuatan yang mereka miliki. Kekuatan yang dimaksud adalah nilai-nilai kepedulian, kegotong royongan, kesetiakawanan, dan pola hubungan kekerabatan yang sudah ada. Pelaksana kegiatan dalam implementasi model intervensi adalah TKM, masyarakat RW 18 Kelurahan Sadang Serang, dan instansi terkait. Kelompok sasarannya adalah stakeholders dan masyarakat RW 18 Kelurahan Sadang Serang.

Secara umum tujuan yang ingin dicapai adalah untuk meningkatkan kontrol sosial masyarakat dalam upaya pencegahan penyalahgunaan NAPZA di RW 18 Kelurahan Sadang Serang. Secara khusus tujuan yang ingin dicapai, yaitu: (1) Untuk meningkatkan pengetahuan dan pemahaman masyarakat tentang masalah penyalahgunaan NAPZA, (2) Untuk meningkatkan kepedulian masyarakat dalam pencegahan penyalahgunaan NAPZA, (3) Untuk meningkatkan pengawasan/peran dari keluarga (orang tua) terhadap kenakalan remaja, serta (4) Untuk meningkatkan akses masyarakat terhadap informasi tentang masalah penyalahgunaan NAPZA

\section{Gambaran Implementasi Model Peningkatan Kontrol Sosial Masyarakat}

Implementasi model intervensi merupakan tahapan paling penting dalam pengembangan masyarakat. Hal ini dilakukan peneliti bersama 
dengan kelompok sasaran sebagai penerima langsung manfaat (direct beneficaries) maupun sistem pendukung (support system). Tujuannya untuk mengatasi masalah dan memenuhi kebutuhan masyarakat berdasarkan pada rencana yang telah disusun secara bersama dan disepakati. Tahapan ini berisi tindakan aktualisasi bersinergi peneliti bersama dengan masyarakat RW 18 Kelurahan Sadang Serang.

Pelaksanaan kegiatan Penyuluhan dan Sosialisasi dilakukan bersama masyarakat RW 18 dan perwakilan 21 RW Kelurahan Sadang Serang pada hari Minggu, tanggal 11 Oktober 2015, pukul 09.30 WIB s/d selesai bertempat di Masjid Subulussalam RW 18 Kelurahan Sadang dengan jumlah peserta 50 orang (daftar hadir terlampir). Pemberian Penyuluhan dan Sosialisasi tentang masalah penyalahgunaan NAPZA dikemas dalam dialok interaktif. Kegiatan diawali dengan pemberian materi yang disampaikan oleh pemateri/narasumber, yaitu: Kompol. Ansari Fuad, S.H. (BNN Kota Bandung) berkaitan dengan "Pencegahan dan Rehabilitasi bagi Korban Penyalahguna Narkoba" dan Aiptu Cory (Satuan Reserse Narkoba Polrestabes Bandung) berkaitan dengan "Pengenalan dan Bahaya Narkoba Dilihat dari Aspek Hukum, serta Mekanisme Penanganan Kasus Pemakai/Pengguna Narkoba". Pada saat paparan Penyuluhan dan Sosialisasi berlangsung, masyarakat menyimak dengan penuh keseriusan apa yang disampaikan oleh pemateri/narasumber. Bahkan, beberapa masyarakat antusias dalam mengajukan pertanyaan. Secara operasional yang mendukung hasil dari pelaksanaan kegiatan Penyuluhan dan Sosialisasi ditandai oleh beberapa hal, yaitu: beberapa masyarakat secara berulang-ulang menyampaikan kesiapannya untuk menghadiri kegiatan, banyaknya jumlah masyarakat yang hadir dalam mengikuti kegiatan, masyarakat serius dalam menyimak materi yang disampaikan oleh narasumber/pemateri, dan masyarakat antusias mengajukan pertanyaan saat kegiatan berlangsung. Selain itu juga, dengan adanya kegiatan Penyuluhan dan Sosialisasi dapat merubah pengetahuan dan pemahaman masyarakat yang sebelumnya bersikap permisif berubah menjadi negatif, serta bagi para pelaku yang menyalahgunakan NAPZA muncul rasa malu dikarenakan masyarakat sekitar mulai menolak keberadaan mereka.

Pelaksanaan kegiatan Kampanye Sosial dilakukan bersama TKM dan masyarakat RW 18 Kelurahan Sadang Serang yang didampingi oleh peneliti pada hari Minggu, tanggal 11 Oktober 2015, pukul 14.00 WIB s/d selesai bertempat di Masjid Subulussalam, Lapangan Badminton, Gapura RW 18, dan Rumah masyarakat RW 18 Kelurahan Sadang dengan jumlah peserta 15 orang (daftar hadir terlampir). Tujuannya adalah untuk memberikan informasi kepada masyarakat tentang masalah penyalahgunaan NAPZA, serta untuk meningkatkan pengetahuan dan pemahaman masyarakat tentang masalah penyalahgunaan NAPZA melalui pemasangan Spanduk dan X-Banner, serta penyebaran Leaflet, Stiker, Buku Saku, dan CD Video. Melakukan kegiatan Kampanye Sosial tentang masalah penyalahgunaan NAPZA adalah wujud dari kepedulian masyarakat terhadap pencegahan masalah penyalahgunaan NAPZA. Pada saat pelaksanaan Kampanye Sosial berlangsung, beberapa masyarakat ikut membantu pemasangan Spanduk dan X-Banner, serta penyebaran Leaflet, Stiker, Buku Saku, dan CD Video. Pelaksanaan Kampanye Sosial ditentukan pada tempat yang strategis untuk pemasangan dan penyebarannya. Hal ini dilakukan untuk mempermudah masyarakat dalam melihat dan mengaksesnya. Secara operasional yang mendukung hasil dari pelaksanaan kegiatan Kampaye Sosial ditandai oleh beberapa hal, yaitu: beberapa masyarakat yang tidak tergabung ke dalam TKM (Tim Kerja Masyarakat) ikutmembantu pemasangan Spanduk dan X-Banner, anak-anak dan remaja yang sedang bermain futsal di lapangan badminton ikut membantu pemasangan Spanduk dan X-Banner, masyarakat yang melintas di sepanjang jalan RW 18 ikut menyaksikan pemasangan dan penyebaran Spanduk, X-Banner, Leaflet, Stiker, Buku Saku, dan CD Video, serta masyarakat menyambut baik dan mendukung adanya pemasangan dan penyebaran Leaflet, Stiker, Buku Saku, dan 
CD Video di rumah-rumah. Selain itu juga, tidak ada tampak lelah yang terlihat pada wajah TKM (Tim Kerja Masyarakat) dan masyarakat RW 18 Kelurahan Sadang Serang saat kegiatan berlangsung. Bahkan, tidak sedikit dari mereka yang berorasi tentang penolakan terhadap penyalahgunaan NAPZA.

Pelaksanaan kegiatan Pembentukan Organisasi Lokal "Pemuda Anti NAPZA" dilakukan bersama TKM dan masyarakat RW 18 Kelurahan Sadang Serang yang didampingi oleh peneliti mulai hari Selasa, tanggal 13 Oktober 2015 s/d hari Sabtu, tanggal 17 Oktober 2015 bertempat di rumah Ibu Kader PKK RW 18 Kelurahan Sadang Serang dengan jumlah peserta 17 orang (daftar hadir terlampir). Pembentukan Organisasi Lokal "Pemuda Anti NAPZA" pada pertemuan pertama hari Selasa, tanggal 13 Oktober 2015 membahas tentang Nama, Tujuan, Semboyan, Latar Belakang, dan Dasar Hukum. Pembentukan Organisasi Lokal "Pemuda Anti NAPZA"pada pertemuan kedua hari Kamis, tanggal 15 Oktober 2015 membahas tentang Struktur Organisasi, Visi, Misi, Tujuan, dan Sasaran. Pembentukan Organisasi Lokal "Pemuda Anti NAPZA" pada pertemuan ketiga hari Sabtu, tanggal 17 Oktober 2015 membahas tentang Kebijakan dan Program, yaitu: Jangka Pendek (Mading NAPZA dan Opini Tempel), Jangka Menengah (Pembuatan Kaos NAPZA, Aksi Pembubuhan Tangan, dan Kunjungan ke Panti Rehabilitasi/IPWL), serta Jangka Panjang (Penyuluhan/Sosialisasi dan Terapi NAPZA). Pada saat proses Pembentukan Organisasi Lokal "Pemuda Anti NAPZA", TKM dan masyarakat RW 18 Kelurahan Sadang Serang mengikuti kegiatan dengan penuh semangat. Hal ini dikarenakan mereka merupakan bagian dalam Organisasi Lokal "Pemuda Anti NAPZA". Organisasi Lokal "Pemuda Anti NAPZA" didalamnya terdapat struktur kepengurusan, tupoksi pengurus dan anggota, serta rancangan program jangka pendek, menengah, dan panjang. Organisasi Lokal "Pemuda Anti NAPZA" yang dibentuk inilah nantinya dijadikan sebuah rencana tindak lanjut dari penelitian yang dilakukan oleh peneliti. Secara operasional yang mendukung hasil dari pelaksanaan kegiatan Pembentukan Organisasi Lokal "Pemuda Anti NAPZA" ditandai oleh beberapa hal, yaitu: masyarakat yang tergabung dalam TKM (Tim Kerja Masyarakat) sangat antusias mengikuti kegiatan dikarenakan terlibat dalam keanggotaan Organisasi Lokal "Pemuda Anti NAPZA", masyarakat berpartisipasi aktif dalam memberikan masukan terhadap Pembentukan Organisasi Lokal "Pemuda Anti NAPZA", serta banyaknya program yang dirancang untuk kepengurusan Organisasi Lokal "Pemuda Anti NAPZA" 1 tahun ke depan.

Pada tahap implementasi model intervensi, peneliti merasa terbantu dengan adanya dukungan, kerjasama, dan partisipasi yang berasal dari pelaksana kegiatan. Terdapat banyak partisipasi aktif masyarakat yang disatukan dalam TKM, sehingga bisa mempermudah implementasi model intervensi yang sudah direncanakan sebelumnya. Hambatan dan tantangan yang dihadapi dalam implementasi model intervensi, maupun kekuatan dan peluang yang dapat dijadikan solusi, yaitu: (1) Hambatan dalam implementasi model intervensi yang dirasakan, yaitu penentuan waktu pelaksanaan dan sering terlambatnya kelompok sasaran ketika akan menghadiri implementasi model intervensi. Waktu yang cukup sulit ditentukan adalah pada saat pelaksanaan kegiatan. Hal ini dikarenakan, pekerjaan dan kesibukan pelaksana kegiatan itu sendiri, (2) Tantangan, fenomena masalah penyalahgunaan NAPZA yang terjadi tidak bisa ditanganihanyadengan satu pendekatansaja, tetapi memerlukan pendekatan yang menyeluruh. Hal ini dikarenakan, permasalahan yang dipengaruhi oleh berbagai faktor yang melatar belakanginya. Hal ini menjadi tantangan bagi peneliti untuk dapat mengaplikasikan pengetahuan, keterampilan, dan nilai yang dimilikinya dalam upaya pencegahan penyalahgunaan NAPZA, (3) Kekuatan, implementasi model intervensi dapat berjalan dengan baik. Hal ini terlihat dari adanya ketersediaan tempat, waktu, sumber daya manusia, sumber pendanaan, peralatan dan perlengkapan, serta anggaran biaya pada saat berlangsungnya 
implementasi model intervensi. Selain itu juga, kekuatan yang menjadi motor penggeraknya adalah tekad dan semangat pelaksana kegiatan untuk mengimplementasikan model intervensi, serta (4) Peluang dalam implementasi model intervensi, yaitu adanya kesempatan peneliti untuk mengaplikasikan ilmu yang telah diperoleh selama mengikuti kuliah di Program Pendidikan Pascasarjana Spesialis-1 Pekerjaan Sosial STKS (Sekolah Tinggi Kesejahteraan Sosial) Bandung. Selain itu juga, dukungan dan apresiasi dari BNN (Badan Narkotika Nasional) Kota Bandung, BNN (Badan Narkotika Nasional) Kota Bandung, Kecamatan Coblong, dan Kelurahan Sadang Serang merupakan peluang yang harus dimaksimalkan pelaksana kegiatan untuk mengimplementasikan model intervensi yang telah rencanakan.

\section{Gambaran Model Akhir Peningkatan Kontrol Sosial Masyakakat}

Evaluasi merupakan aktivitas yang dilakukan untuk mengetahui proses dan hasil yang dicapai. Evaluasi dilakukan pada saat implementasi model intervensi telah selesai dilaksanakan. Evaluasi dilakukan peneliti bersama dengan stakeholders dan masyarakat RW 18 Kelurahan Sadang Serang. Penilaian dilakukan dengan memberi skor 1 sampai dengan 5 terhadap setiap pertanyaan yang diberikan. Skor 1 diberikan partisipan apabila kegiatan yang dilakukan sangat tidak bermanfaat atau sangat tidak berhasil. Berturut-turut, skor 2 sampai dengan 5 diberikan partisipan apabila kegiatan yang dilakukan tidak berhasil, cukup berhasil, berhasil, dan sangat berhasil. Hasil evaluasi dengan kedua cara tersebut kemudian dijumlahkan, lalu dibagi 2 untuk mendapatkan nilai rata-rata.

Evaluasi proses dilakukan untuk menilai aspek-aspek pada semua tahap kegiatan, mulai dari persiapan sosial sampai dengan implementasi model intervensi. Partisipan tidak mengalami kesulitan dalam memberikan penilaian, dikarenakan evaluasi proses ini sudah pernah dilakukan pada saat penelitian terdahulu. Eva- luasi hasil dilakukan untuk menilai hasil akhir seluruh kegiatan. Aspek yang dinilai, yaitu ketepatan waktu, ketepatan sasaran, kesesuaian jumlah sasaran, kesesuaian kualitas, perubahan yang terjadi, kesesuaian lokasi, penerimaan masyarakat terhadap program, dan manfaat yang dirasakan masyarakat.

Model akhir yang telah disempurnakan efektif dan cenderung lebih baik untuk mengatasi masalah mendasar yang menyebabkan lemahnya kontrol sosial masyarakat dalam upaya pencegahan penyalahgunaan NAPZA. Terbukti hasil implementasi model intervensi dapat meningkatkan kontrol sosial masyarakat dalam upaya pencegahan penyalahgunaan NAPZA di RW 18 Kelurahan Sadang Serang. Tujuan lain yang dicapai, yaitu: (1) Meningkatnya pengetahuan dan pemahaman masyarakat tentang masalah penyalahgunaan NAPZA, (2) Meningkatnya kepedulian masyarakat dalam pencegahan penyalahgunaan NAPZA, Meningkatnya pengawasan/peran dari keluarga (orang tua) terhadap kenakalan remaja, serta (4) Meningkatnya akses masyarakat terhadap informasi tentang masalah penyalahgunaan NAPZA.

\section{E. Kesimpulan dan Rekomendasi}

\section{Kesimpulan}

Penelitian tentang peningkatan kontrol sosial masyarakat dalam upaya pencegahan penyalahgunaan NAPZA di RW 18 Kelurahan Sadang Serang merupakan jenis penelitian tindakan (action research). Tahapan yang dilakukan dalam penelitian ini adalah identifikasi kontrol sosial masyarakat, perencanaan model, implementasi model, dan model akhir. Setiap tahapan melibatkan stakeholders, masyarakat RW 18 Kelurahan Sadang Serang, serta instansi terkait.

Berdasarkan hasil asesmen ditemukan beberapa masalah terkait kontrol sosial masyarakat, yaitu: (1) Masyarakat kurang memahami dan mengetahui tentang masalah penyalahgunaan NAPZA, (2) Sosialisasi tentang bahaya 
penyalahgunaan NAPZA belum pernah dilakukan, (3) Masyarakat kurang peduli terhadap masalah penyalahgunaan NAPZA,

Masyarakat membiarkan apabila ada warganya yang mengkonsumsi minuman alkohol, (5) Tidak berfungsinya stakeholders dalam pencegahan penyalahgunan NAPZA, (6) Masyarakat tidak mengetahui adanya pelayanan rehabilitasi terhadap korban penyalahguna NAPZA, (7) Banyak masyarakat yang nongkrong sambil berjudi pada malam hari, serta (8) Keluarga (orang tua) kurang mengawasi terhadap kenakalan remaja.

Hasil asesmen akan dijadikan acuan dalam penyusunan perencanaan model intervensi. Untuk persiapan dalam menyusun perencanaan model intervensi, maka terlebih dahulu peneliti bersama dengan TKM melakukan konsultasi. Pelaksanaan konsultasi melibatkan pihak yang berkompeten, meliputi BNN (Badan Narkotika Nasional) Kota Bandung, BNN (Badan Narkotika Nasional) Provinsi Jawa Barat, dan Satuan Reserse Narkoba Kepolisian Resort Kota Besar Bandung. Tujuannya untuk mengetahui pandangan mereka tentang upaya pencegahan penyalahgunaan NAPZA di RW 18 Kelurahan Sadang Serang yang akan direncanakan dan dilaksanakan bersamasama dengan TKM. Adapun rincian kegiatan dari hasil penyusunan perencanaan model intervensi, yaitu Penyuluhan dan Sosialisasi, Kampanye Sosial, dan Pembentukan Organisasi Lokal "Pemuda Anti NAPZA". Semua kegiatan akan dilaksanakan secara terorganisir dalam rangkaian proses yang telah direncanakan.

Kegiatan dalam implementasi model intervensi mampu meningkatkan kontrol sosial masyarakat dalam upaya pencegahan penyalahgunaan NAPZA di RW 18 Kelurahan Sadang Serang. Hasil lain yang dicapai dalam implementasi model intervensi, yaitu:(1)Meningkatnya pengetahuan dan pemahaman masyarakat tentang masalah penyalahgunaan NAPZA, (2) Meningkatnya kepedulian masyarakat dalam pencegahan penyalahgunaan NAPZA, (3) Meningkatnya pengawasan/peran dari keluarga (orang tua) terhadap kenakalan remaja, serta (4) Meningkatnya akses masyarakat terhadap informasi tentang masalah penyalahgunaan NAPZA.

Model akhir yang telah disempurnakan efektif dan cenderung lebih baik untuk mengatasi masalah mendasar yang menyebabkan lemahnya kontrol sosial masyarakat dalam upaya pencegahan penyalahgunaan NAPZA. Terbukti hasil implementasi model intervensi dapat meningkatkan kontrol sosial masyarakat dalam upaya pencegahan penyalahgunaan NAPZA di RW 18 Kelurahan Sadang Serang.

\section{Rekomendasi}

Berkaitan dengan proses pelaksanaan penelitianini, adabeberapakemajuanyang telah dicapai oleh masyarakat dan ada juga kegiatan yang masih harus dikembangkan untuk lebih meningkatkan pencapaian yang sudah diperoleh. Untuk itu, ada hal-hal yang dirasa perlu direkomendasikan sebagai bahan pertimbangan kepada pihak-pihak terkait, yaitu: (1) Bagi Pemerintahan Daerah: (a) Agar pemerintah lebih aktif dalam menerapkan kebijakan terkait pencegahan dan penanganan masalah penyalahgunaan NAPZA, pemerintah mampu bekerja sama dan menjadi mitra kerja bersama masyarakat, (b) Agar pelaksanaan kegiatan penyuluhan dan sosialisasi dilakukan kembali oleh pemerintah minimal 2 bulan sekali dalam upaya keberlanjutan program intervensi, serta (c) Pemerintah harus memberdayakan masyarakat secara mandiri dengan pemberian informasi dan penyadaran tentang bahaya penyalahgunaan NAPZA, (2) Bagi Kelurahan Sadang Serang: (a) Aparat Kelurahan dan Brigadir RW 18 Kelurahan Sadang Serang agar terus memberikan pembinaan kepada Organisasi Lokal "Pemuda Anti NAPZA", sehingga ada keberlanjutan terhadap program intervensi, (b) Melalui media pertemuan yang ada di Kelurahan, dapat dilakukan sosialisasi tentang pentingnya peningkatan kontrol sosial masyarakat dalam upaya pencegahan penyalahgunaan NAPZA, serta (c) Program yang diluncurkan melalui Kelurahan tidak hanya diperuntukkan bagi pembangunan saja, tetapi juga untuk kegiatan di bidang sosial kemasyarakatan terutama untuk 
masalah penyalahgunaan NAPZA, serta (3) Bagi Organisasi Lokal "Pemuda Anti NAPZA": (a) Terus melanjutkan program intervensi terkait pencegahan dan penanganan penyalahgunaan NAPZA yang telah disusun bersama peneliti, (b) Mengadakan koordinasi dan menjalin kerjasama dengan berbagai pihak untuk mendukung pelaksanaan program kerja Organisasi Lokal "PemudaAntiNAPZA",(c) Melakukan mobilisasi pengurus dan anggota Organisasi Lokal "Pemuda Anti NAPZA" dengan tujuan agar lebih aktif dan kreatif memunculkan kegiatan pencegahan dan penanganan penyalahgunaan NAPZA.

\section{Daftar Pustaka}

Edi Suharto. (2009). Kemiskinan dan Perlindungan Sosial di Indonesia: Menggagas Model Jaminan Sosial Universal Bidang Kesehatan. Bandung: Alfabeta.

Isbandi Rukminto Adi. 2008. Intervensi Komunitas Pengembangan Masyarakat Sebagai Upaya Pemberdayaan Masyarakat. Jakarta: Rajagrafindo Persada.

Johnson, Jerry L. 2004. Fundamentals of Subtance Abuse Pratice. Canada: Thomson Learning, Inc.

Sloboda, Zili \& Bukoski, William J. 2006. Handbook of Drug Abuse Prevention. New York: Springer Science Business Media.

Siti Waridah Q. dan J. Sukardi. (2003). Sosiologi 1. Jakarta: PT Bumi Aksara.

Soerjono Soekanto. (2007). Pengendalian Sosial dalam Masyarakat. Jakarta: Rajawali Pers.

Sugiyono. 2014. Memahami Penelitian Kualitatif. Bandung: Alfabeta.

Sussman, Steve \& Ames, Susan L. 2008. Drug Abuses Concept, Prevention, and Cessation. Cambridge: Cambridge University Press.

Suwarsih Madya. 2011. Penelitian Tindakan. Action Research. Bandung: Alfabeta.

Tan, Ngoh-Tiong \& Envall, Elis. 2000. Social Work: Challenges in the New Millenium. Switzerland: IFSW Press. 